\title{
Efficient Components on Livestock Products Export in Iran
}

\author{
Behnam Maleki ${ }^{1}$, Farhad Mirzaei $^{2 *}$ \\ ${ }^{1}$ State Agrarian University of Armenia, Yerevan, Armenia \\ ${ }^{2}$ Livestock Production Management, Animal Science Research Institute of Iran, Karaj, Iran \\ Email: *farmir2003203@yahoo.com
}

Received October 1, 2012; revised November 8, 2012; accepted December 18, 2012

\begin{abstract}
Iran's dependence on oil revenues has caused severe impact of commodity price fluctuations on the currency revenues and any reduction in export prices has led into a deficit in the country's balance of payments. Accordingly, it was in the past years and especially the Second Development Plan that government included encouragement and reducing the country's dependence on oil revenues in its agenda. The international agricultural exports, especially exports of livestock and poultry country subdivision have a proper status due to its relative advantage. Therefore, in this study factors affecting the supply of exportable animal products are considered. For this purpose, factors affecting exports of livestock products are studied by using Cointegration Analysis based on statistical intervals in 1984-2008. Experimental results showed that the value of income per capita importer countries of Iran and the real exchange rate had a positive effect on export demand and the added value and export price index had a negative impact on exports of livestock sector.
\end{abstract}

Keywords: Livestock; Exports; Value Added; Price Index; Cointegration Analysis

\section{Introduction}

Common in economic theories, trade and especially exports are recognized as engines of economic growth. Particularly, its importance is doubled in international economy literature due to economic growth and development in Southeast Asian countries. At the moment and in order to diversify country's foreign incomes in international markets, developing non-oil exports is considered as an inevitable necessity for the country. To fully aware of the conditions governing the export of a country, three areas of product generation, marketing, export and transfer and procurement should be examined. One problem in developing countries including Iran is over-reliance foreign incomes or multiproduct which destabilizes foreign incomes $[1,2]$. Iran's past experience in the field of foreign exchange volatility necessitates policy-making on increasing non-oil exports particularly agricultural products. To the same reason, it is particularly important to identify affecting factors of exporting such goods [3]. Thus, factors affecting the livestock product exports are selected and analyzed in present research as our target.

Basically, the formation of a strong export sector in the long term needs to adopt appropriate policies in this regard. On the other hand, these policies are not possible

${ }^{*}$ Corresponding author. without understanding and determining the factors affecting export. So, in order to strengthen the agricultural sector and increase its exports, it is necessary to determine its affecting factors. On the other hand, success in the export of any goods including agricultural production requires three fundamental initiatives including substantial competitive actions, identifying target markets and accurate and timely transferring of competitive products to target markets. Accordingly, this paper has the following structure: the introduction is followed by livestock and poultry export situation. In the third part, previous studies in the field of agricultural exports are reviewed. Section 4 is devoted to research methodology. Section 5 contains estimates made and the analysis of factors affecting the exports of livestock products and in the end some conclusions and recommendations are presented.

\section{Studying the Status of Agricultural Exports with Emphasis on Livestock and Poultry Products}

Livestock and poultry products exportation includes 87 tariffs, which their volume and value have been shown in Figures 1 and 2. Total exports of animal products increased from 75 thousand tones in 2001 to 236.6 thousand 


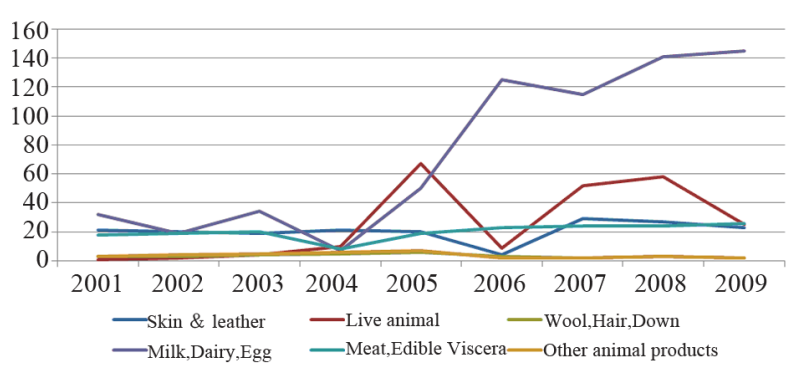

Figure 1. Volume of Iranian animal products export (1000 tones).

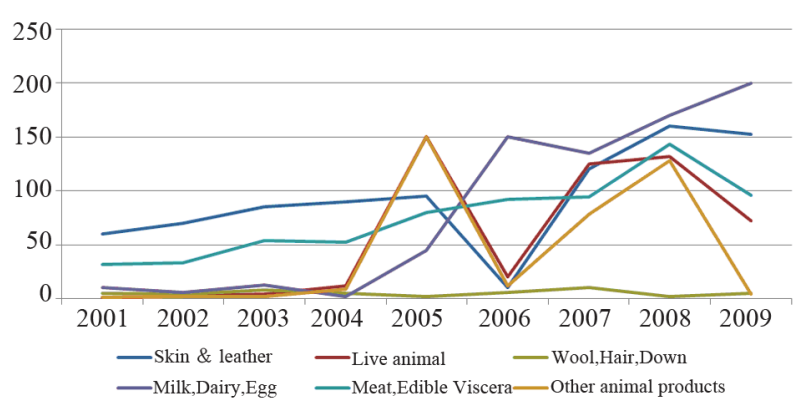

Figure 2. Value of Iranian animal products export (million\$).

tones in 2009 (average annual growth rate of 15.4 percent). Among the products of this subsection, the highest volume of exports belongs to milk, dairy products, eggs and other products, so that the share of total goods export volume of this subsection increased from 44.3 percent in 2001 to over 62 percent in 2009. This Product Group is followed by skin and leather exports though its share is declined during this period from 30.3 percent to 10.3 percent. In terms of export value in this period, livestock and poultry exports subdivision with average annual growth rate of 18.8 percent reached from 139 US\$ in 2001 to about half a billion. Among the products of this subsection, skin and leather, milk and dairy products have the highest share of export value. In order to study trends and factors affecting on livestock product export changes, it is necessary to examine the exportation of each animal product in the first stage separately. In this line, annual statistics in 2001-2009 are selected and analyzed.

\subsection{Skin and Leather Exports}

In 2001 to 2009 , by a negative average growth rate of $0.85 \%$, the rate of skin and leather exports decreased to 22.8 to 24.4 thousand tones. However, the value of its exports in this period increased from 69 million to 155 million dollars. Skin export in different years has remained almost constant. But anyway, animal husbandry sector is one of the most important export items which embrace a significant share of the livestock export activi- ties. Skin export depends on livestock slaughter in that year and the absorption potency of domestic industries. Previously, there were no leather and skin industries in the country. So, all the raw skin was exported. Now, some part of the product is consumed domestically and its surplus that may is exported.

\subsection{Milk, Dairy Products and Eggs}

In the early years of $1990 \mathrm{~s}$, Iran was a net importer of dairy products and eggs while exportation of such products has been on the agenda in recent years though its value has been fluctuating in recent years. However, it has been a soaring trend so that exportation rate increased from 33 thousand tones in 2001 to about 147 thousand tones in 2009 (average annual growth rate of $20.4 \%$ ). The value of exportation growth of these goods was higher than their volume (33.3\%) and reached to 203 million dollars from about 20 million dollars during the same period.

\subsection{Export of Live Animals}

Although the rate of exporting live animal is now negligible, it has been grown in recent years. By annual average growth of $4.9 \%$, the exportation of such goods increased to 57.9 thousand tones in 2008 from 57.9 tons in 2001 while it decrease $50 \%$ in 1009 . In terms of the export value of live animals in this period, it increased from 2 to 71 million dollars by $58.3 \%$ as growth rate. In the meantime, non-price policies also play an important role in live cattle exports.

\subsection{Exports of Wool, Hair and Shaggy}

After the skin, wool export has a significant share of total exports of animal products. In 2001-2009, the exportation of these goods increased from 2.2 to 3.2 thousand tones with average annual growth rate of $4.9 \%$. Also in terms of value, the value of goods shows a growth from 12 to 14 million dollars. Exports of these products fluctuated during various years due to the lack of exportation in one year and its increase in another year.

\subsection{Exports of Meat and Edible Viscera}

Exports of meat and edible viscera in recent years have increased from 14 tons in 2001 to about 31 thousand tons in 2009. Most of these exports are devoted to edible viscera and the share of meat export is negligible. During the same period, the value of these goods increased to 95 million dollars from 32 million dollars. In recent years, however, meat exportation has been feasible due to increase in its domestic production. In some years, the aim of meat exportation was to adjust the market. It means that meat is exported in season of demand surplus and it 
is imported when its shortage is felt.

\subsection{Other Animal Products}

Other animal products include honey, wax, honey, other edible viscera, rumen and intestines. Intestines exportation backs to past years. Perhaps, its value is fixed, but exports of honey and honey wax have recently increased considerably. Exports of these goods have increased from 1.9 thousand tones in 2001 to 5.8 thousand tones in 2008 while it decreased to 2.2 thousand years in 2009 .

\section{Overview of Previous Studies}

Regarding agricultural product exports, studies are mainly conducted by using econometric methods, but they are also taken in the context of some other methods, including SWOT analysis to examine strengths, weaknesses, opportunities and threats facing agriculture export that the real exchange rate deviation from long run equilibrium path, the real exchange rate fluctuations and the pressure of domestic demand for exportable goods impact on the supply of agricultural exports negatively and the relative price of exportable agricultural products, sudden changes in agricultural production and technical advances impact on the supply of agricultural products exports positively [4]. It has been also studied a new outlook on non-oil product exports and examined affecting impacts on the supply exportable animal products [5]. Khalilian and Farhadi [6] showed that agricultural value added (production capacity), the relative prices of exports and domestic consumption (domestic demand) have a significant impact on supplying agricultural product exports, whereas the effect of real exchange rate on exports of agricultural products supply is not significant which shows the reason of inappropriateness of governmental foreign exchange policies agricultural product exports in studied period. Shakeri [7] studied the role played by cost and non-cost factors in non-oil exports using the ARDL technique and concluded that non-oil exports depends on productivity variables and competitiveness and although exchange rate variables have a positive effect on exports, this effect is not significant and decisive. While removing cost effective performance obstacles to increase Exports, the on non-cost variables such as productivity and competitiveness should be emphasized too. In their study, Biria and Jabal Ameli [2] examined the factors affecting pistachios, saffron, dates in the basket of Iranian goods exportation. Results of studies indicate that price policies have no positive impact on revenue from no-noil exports. Therefore, those policies should be devised that lead to encourage and increase production as well as to supply agricultural products and their diversification. Paspan [1] studied factors affecting Iran's saffron exports using export supply func- tion. Results show that the ramifications from export supply function estimations indicate that production and real exchange rate had a positive impact on this commodity and during the same period, export prices and war had a negative impact on Saffron Export. Statistical surveys indicated that foreign exchange earnings from saffron exports in this period were unstable which the reason was export demand, not supply. Finally, it is suggested while paying attention to product processing, effective and stable trade and currency policies can be influential in increasing saffron export to world markets. Zibaei and Mahmoodzadeh [8] studied the factors affecting the export of Iranian pistachios by using ARDL technique. Studied variables affecting the supply of pistachio exports in this study were logarithmic index of currency changes and the actual retail price of pistachio. To evaluate short and long term relationships between pistachio export and and other explanatory variables according to the proportion of the characteristics of studied data about, logarithmic functional form and Cointegration analysis approach called ARDL were used. The results of this study indicate that exchange rate changes on short and long term do not have a significant impact on pistachio export, but the retail price index variable is significant and positive impact in the long run. In addition, the results of short-term relationship show that about 58 percent of export supply short-term deviations from the long-term equilibrium value would be moderated over the same period. In other words, it takes two years to moderate the results of executing a policy completely. This optimal speed of adjustment paves a favorable ground for implementing incentive export policies.

Noory and Kupahy [9] studied estimates on pistachio demand and supply functions. The results showed that pistachio export demand elasticity is -0.389 relative to exchange rate which shows that the exchange rate changes have a negative impact of on revenue from pistachio exports. Tajyany and Kupahy [10] estimated supply and demand functions of Iranian saffron export by simultaneous equations model system using estimated data in 1974-2000. Export demand price elasticity is equal to -2.1 which shows that one percent increase in the price of Iran's saffron export decreases export demand as $2.1 \%$. On the other hand, there is no significant relation between Spanish saffron export prices and demand for Iran export. Although this variable is positive and shows that increase in Iranian saffron demand is simultaneous to increase in Spanish saffron export price, Spanish saffron is a substitutive product for Iranian saffron in global markets. Income elasticity of world demand for saffron is 1.2 in the short term, indicating that saffron is luxury consuming merchandise. Accordingly, one can conclude that 10 percent increase in saffron importers' incomes would increase demand for exports by 
12 percent. In long term the rate of elasticity would increase to 2.3. Negative export demand elasticity to real exchange rate implies that increase in real exchange rate or decrease in purchasing power of importing countries' national currency impacts on the demand of Iranian saffron exports adversely and reduces their purchasing power. The estimated amount of this elasticity is -0.88 which would be increased to -1.69 in the long run. Saffron export has a positive and significant impact on export demand function with a time, indicating that the degree of dynamic adjustment. Effects of trade liberalization (1992 onwards) in the export demand function is positive and significant; indicating that the positive effect of trade with countries increased trade barriers and eliminate the demand for exports Iranian saffron. Estimating export supply price elasticity indicates that shortterm export supply is 3.35 and shows that one percent increase in export prices leads to $3.35 \%$ increase in export supply. Variable ratio in domestic production of saffron export supply function is being normalized and is highly significant based on export prices and has the relevant mark with theory. Export price index with a time interval is 0.44 and significant. Fountas and Berdin [11] used Cointegration technique and error correction model to study the impact of exchange rate changes on exports from Ireland to England. In this study, long-term relationship with Irish exports was estimated by using Cointegration Technique. To determine the short-term relationship between exchange rate changes and exportation, model error correction was used. Moving SD indicators in the real exchange rate growth rate was used as a measure of exchange rate changes. The results showed that exports in the long run depend on the importers' income and relative prices significantly. According to the estimated error correction model, exchange rate changes reduce exports from Ireland to England only in the short term. Tayebi and Ghanbari [12] studied the factors affecting supply and demand of Iranian saffron export by using simultaneous equations system. The results show that foreign income variables and exports saffron interrupt have positive and significant effects (at 1 and 10 percent levels) on Iran's saffron export demand but relative price of exports does not have a significant coefficient which shows the ineffectiveness of this variable in saffron export demand. In export supply model, the price of saffron shows high reaction to changes in the value of saffron gross production. In addition, exchange rate variable has no significant effect on saffron export supply price. Meanwhile, the positive and significant coefficient of WTO variable virtual in export supply equation indicates a significant influence of WTO on saffron export market. To evaluate factors affecting pistachio export, Sharzehi and Ghanbari [13] estimated its supply and demand functions simultaneously. The results of esti- mating export supply function suggest the elasticity of pistachio exports proportionate export price changes. Meanwhile, domestic production and price variables impact on pistachio Iranian exports positively and significantly.

\section{Materials and Methods}

Studies on export demand and supply functions modeling, especially in developing countries, are more addressed to single-equation estimates of export supply, and in some cases, to export demand. But in some cases at macro models, export supply and demand are considered simultaneously (in the form of a system of simultaneous equations). In all studies, while providing export supply model, two variables of relative prices and desired production levels are used as the major explanatory variables. One of the most popular export models is the one introduced by Goldstein and Mohsen Khan [14]. In this model, simultaneous model is introduced to estimate supply and demand functions for export goods and the demand and supply functions of a country as a linear function-despite of the existence of two equilibrium and non-equilibrium models. Equilibrium model assumes that there is no interruption in the system for adjusting the amount of exports and price levels and the system reaches to equilibrium immediately. Non-equilibrium model assumes that exportation is adjusted by considering difference between export demands at time $t$.

Bond pattern in another important model in estimating models estimate export supply and export demand in developing countries which is represented beyond a country or region. This pattern, especially in the supply side, is more comprehensive than Goldstein-Mohsen Khan model [14] and considering a supply shocks and changing trends in the region is highly important in this model. Also in this model, export merchandise prices ratio to domestic prices, especially in a specific goods or specific goods group, has more importance than the theoretical model is more acceptable than Goldstein-Khan because that the internal purchasing power for export in this model has been considered and thus the entry in the exchange rate model and its indirect effect on export supply, being replaced by domestic demand rather than exports (which increased the domestic prices (inflation) or changes in exchange rates and the overall real effective exchange rate) as well as the strengths of this model compared to model introduced by Goldstein-Khan [14] are considered.

In present study, export supply function is estimated as a single equation and independent of the export demand function with the assumption that Iran is a small country in the field of livestock product exports and is a price taker in global market price. In this case, the exportation supply rate is a function domestic price as well as domestic 
determinants. On one hand, due to government policies to support domestic consumers, domestic demand surplus is always exported. On the other hand, according to the nature of agricultural commodities, supplying these goods creates their demand. Therefore, offering a product for export is under the influence of factors such as domestic prices and prices of export products and domestic production. Another variable that affects exports is the exchange rate. For example, Chambers and Just [15] and Fountas and Berdin [11] showed that exchange rate fluctuations can have important effects on agricultural product exports. Other empirical studies also show that changes in real exchange rate changes compared to the nominal supply have more impact on agricultural commodity exports. Hence, it is necessary that the exchange rate as an important variable affecting export being inserted to model so that increase in domestic production, exportation supply would be also increased and vice versa since exportation is domestic supply surplus. Another important variable influencing on the export of agricultural products, particularly livestock and poultry products is rainfall. So the model of export supply in logarithmic mode will be as follows:

$$
\begin{gathered}
\ln X_{t}^{d}=\beta_{0}+\beta_{1} \ln P X_{t}+\beta_{2} \ln P E x_{t}+\beta_{3} \ln E R_{t} \\
+\beta_{4} \ln \operatorname{Pr} O d_{t}+u 2_{t} \\
\Delta \ln X_{t}^{d}=\gamma\left(\ln X_{t}^{d}-\ln X_{t-1}^{d}\right)+u_{3 t}, \gamma \succ 0
\end{gathered}
$$

where $X_{t}^{d}=$ the supply for export, $P X_{1}=$ domestic product prices, $P E x=$ export prices, $E R=$ real exchange rate Prod $=$ the rate of domestic production and Rain $=$ rainfall. Above equation shows export supply function in the long run which is not normally achievable at any moment of time. So by using adjustment mechanism, it is assumed that exportation is moderated proportionate to difference between supply for exportation in time $t$ and actual export amount in previous period: In the above equation, $\gamma$ is the coefficient of adjustment. Adjusted function assumes that if any excess amount of export supply is moderated. In order to study long-term and short term relationships between the dependent variable and other explanatory variables model, one can use the method of Engel-Granger and error correction models (ECM). Engel Method-Granger method is based on reliability variables with single differentiation. Also, this method only considers long-term relationships. In addition to these restrictions, in the cointegration analysis method based on Engel-Granger, the need of precious awareness on the direction of variables' impacts on each other is a limitation. Patterns of short-term relate variables error correction fluctuations to their long term equilibrium values. If the variable is Cointegration Model, the remained is a function of rank zero (reliable) and, as a result, one can estimate the coefficients of error correc- tion model to test without the fear of achieving a false regression by OLS method and use $F$ and $t$ statistics in test method, but if the collective pattern variables are zero and one, it is no longer possible to use error correction model to estimate short term coefficients. Because of these limitations, some studies have tried to overcome these shortcomings and to achieve a better approach in order to analyze long-term and short term relationships between variables, including the outcome of the study, by Pesaran and Pesaran [16] who called it ARDL. According to this method, in addition to meet the informational needs on relationship between variables, it should be possible to investigate the relations between variables while they are a part of them in a reliable level and other part is become reliable by one time differentiation. ARDL method is able to estimate the ability of short and long term components. This method is also able to solve problems related to variable elimination and self-correlation. In the meantime, because these models are generally free of problems such as serial self-correlation and introversion, derived estimates from them will straightforward and efficient. One can write extended ARDL model follows:

$$
\alpha(L, p) y_{t}=\alpha_{0}+\sum_{i={ }^{k}}^{k} \beta_{i}(L, p) x_{i t}+\ln X_{t-1}^{d}+u_{t}
$$

where: $\alpha_{0}=$ the width of the origin, $y_{1}=$ the dependent variable, $x_{i t}=i$ independent variable and $L=$ the delay factor defined as follows:

$$
\begin{gathered}
L^{j} y_{t}=y_{t-j} \\
\beta_{i}(L, p)=\beta_{i 0}+\beta_{i 1} L+\beta_{i 2} L^{2}+\cdots+\beta_{i q} L_{i}^{q}, \alpha(L, p) \\
=1-\alpha L^{1}-\cdots-\alpha L^{p}
\end{gathered}
$$

Based on the logarithmic form for the ARDL model export supply would be as follows:

$$
\begin{aligned}
\ln X_{t}^{d}= & \alpha_{0}+\sum_{i-1}^{m} \beta_{i} \ln X_{t-i}^{d}+\sum_{i-1}^{n} \varepsilon_{i} \ln P X_{t-i} \\
& +\sum_{i=1}^{f} \gamma_{i} \ln \operatorname{Pr} o d_{t-i}+\sum_{i=1}^{k} \lambda_{i} \ln E R_{t-i} \\
& +\varepsilon_{0} \ln P X_{t}+\gamma_{0} \ln \operatorname{Pr} o d_{t}+\lambda_{0} \ln E R_{t}+u_{1 t}
\end{aligned}
$$

where $m, n, f$ and $k$ are the numbers of optimized interruptions for $\ln X_{t}^{d}, \ln P X_{t}, \ln \operatorname{Pr} o d_{t}, \ln E R_{t}$ variables.

Long-term export supply relationship can be expressed as follows:

$$
\ln X_{t}^{d}=\lambda_{0}+\lambda_{1} \ln P X_{t}+\lambda_{2} \ln \operatorname{Pr} o d_{t}+\lambda_{3} \ln E R_{t}+u_{2 t}
$$

To estimate long-term relationship, one can use a twostep method. Firstly, there is a long term relationship between model variables, which can be explained and investigated by the theory and secondly, if long-term relationship between variables is proved in the first stage, 
short and long term parameters can be estimated by using equations 9 and 8 . To test long-term relationship, one can use $F$ statistic. When such a relationship exists, $F$ test shows significance or insignificance of long-term coefficients statistically. To do this, ARDL model was initially estimated and then below null hypothesis was used to test this long-term relationship: $H_{0}: \varepsilon_{0}-\gamma_{0}=\lambda_{0}-0$.

If stable relationship and $\mathrm{F}$ critical long-term statistics between model variables are proved at the first stage, in the second stage, two-part process would be used to estimate model parameters; at first step, collective degrees of variables will be determined by indices of Akatik or Schwartz and then in the second step, estimating selected model will be conducted by the OLS model. Exporting any goods is influenced by various factors including the real exchange rate, export prices, the current investment, production, domestic prices, etc. Many studies are conducted about the impact of exchange rates on exports and all confirm that fluctuating exchange rates will reduce exports [8]. On the other hand, there is a direct correlation between real exchange rate and export. Hence, real exchange rate is one of the most important variables affecting exports calculated through following equation:

$$
E R_{t}^{r}=E R \frac{C P I_{t}^{d}}{C P I_{t}^{f}}
$$

where $E R_{t}^{r}=$ real exchange rate, $E R=$ the nominal exchange rate and $C P I^{d}$ and $C P I^{f}$ are consumer price index and domestic and foreign consumer index (America here) respectively. As mentioned above, exchange rate variable in export function inserts the model through two ways. In some models, exchange rate fluctuations are entered as an influential variable and in other estimates, real exchange rate is used. The real income of major Importers (based on purchasing power (ppp)) is an effective factor in export demand function and its role in the export supply is not so highlighted. Another important and effective variable on exportation is internal price, more increase in internal price, more decrease in export supply.

\section{Results and Discussion}

Regarding export prices, it shows the existence of a direct relationship with exportation. Because the data used are time series, their statistical stance is initially examined by using generalized statistical static test of DickeyFuller that the results are shown in Table 1. Based on results of the static test, the real exchange rate logarithm variables and export prices logarithm index are in static level and based on the results of generalized statistical static test of Dickey-Fuller, added value logarithm variables, importers' income logarithm and exportation rate logarithm are converted into static level by just one time demand.
Result of long-term relationship estimation by using E-views 6, statistical software is as follows (Table 2).

Results of the estimation indicate the existence of a rational relationship between variables. If the rate of demand for products decreases by increase in product export price, demand rate increases by consumers' income increase and demand rate decreases by increase in actual exchange rate. By comparing the Long-term critical value of F-statistics in desired model with $\mathrm{F}$ table, the result is that long term relationship coefficients are statistically significant. Estimated the long-term equation coefficients show the attraction of demand variables to long term explanatory variables. Based on the results, exchange rate variable coefficient is significant in longterm. On this basis, real exchange rate is one of the important and effective variables in export demand. It should be mentioned that in some studies, instead of

Table 1. Results of existence trend of variables.

\begin{tabular}{|c|c|c|c|c|c|c|}
\hline \multicolumn{3}{|c|}{ Critical values } & \multirow{2}{*}{$\begin{array}{l}\text { trend existence } \\
\text { and width from }\end{array}$} & \multirow{2}{*}{ t-statistic } & \multirow[b]{2}{*}{ Test } & \multirow{2}{*}{$\begin{array}{l}\text { Desired } \\
\text { variable }\end{array}$} \\
\hline $\begin{array}{c}10 \\
\text { percent }\end{array}$ & $\begin{array}{c}5 \\
\text { percent }\end{array}$ & $\begin{array}{c}1 \\
\text { percent }\end{array}$ & & & & \\
\hline-2.6251 & -2.9718 & -3.6891 & Both & -2.9386 & $1 *$ & \\
\hline-1.6095 & -1.9538 & -2.6534 & Both & -0.1157 & $2 *$ & \\
\hline-2.6251 & -2.9718 & -3.6891 & Both & -3.2680 & $3 *$ & \\
\hline 2.6734 & -3.0655 & -3.9203 & Both & -1.9378 & $1^{*}$ & \\
\hline-1.6056 & -1.9644 & -2.7175 & Both & -1.8552 & $2 *$ & \\
\hline-2.6734 & -3.0655 & -3.9203 & Both & -1.9651 & $3 *$ & \\
\hline-2.6326 & -2.9862 & -3.7240 & Both & -1.5453 & $1 *$ & \\
\hline-1.6084 & -1.9564 & -2.6693 & Both & -0.9606 & $2 *$ & \\
\hline-2.6274 & -2.9762 & -3.6998 & Both & -1.6678 & $3 *$ & \\
\hline-2.6274 & -2.9762 & -3.6998 & Both & -0.6779 & $1^{*}$ & \\
\hline-1.6095 & -1.9538 & -2.6534 & Both & 0.8613 & $2 *$ & \\
\hline-2.6251 & -2.9718 & -3.6891 & Both & -2.1237 & $3 *$ & \\
\hline-2.6551 & -3.0299 & -3.8315 & Both & -0.9597 & $1 *$ & \\
\hline-1.6070 & -1.9601 & -2.6923 & Both & -0.8766 & $2 *$ & of \\
\hline-2.6551 & -3.0299 & -3.8315 & Both & -0.7774 & $3 *$ & \\
\hline
\end{tabular}

Source: Research results.

Table 2. Results of estimating export demand long-term relationship.

\begin{tabular}{ccccc}
\hline $\begin{array}{c}\text { Standard } \\
\text { deviation }\end{array}$ & Coefficient & Variable \\
9.508 & -4.528 & $\begin{array}{c}\text { Width from the origin } \\
\text { Logarithm of export } \\
\text { price }\end{array}$ & $\mathrm{cn} P X_{t}$ \\
1.004 & 4.456 & $\begin{array}{c}\text { Logarithm of } \\
\text { Importers' income } \\
\text { Logarithm of real } \\
\text { exchange rate }\end{array}$ & $\operatorname{Ln} Y w_{t}$ \\
\hline $\begin{array}{c}\text { F-statistic }= \\
24.130\end{array}$ & $\mathrm{DW} E R_{t}$ \\
\hline
\end{tabular}

Source: Research results. 
using real exchange rates, exchange rate changes are used [8]. Added value is another important variable of export price index for livestock and poultry products which has a negative impact on export demand of these products. On the other hand, more increase in added value of livestock and poultry subsection, decrease in its goods export demand. It shows that Iran's export target markets are not ultimate target markets and these markets import Iran's initial products by the aim of re-export after reprocessing. Thus, the relationship between value added and export demand is negative.

Real income of Iranian export target countries Iran is another variable affecting on export demand. In the stud- ied period, the most important target markets of Iranian livestock and poultry products export include Germany, Italy, Turkey, France, Spain, Russia, Austria, Switzerland and Belgium. On this basis, it expects that by increase in per capita income of these countries (in terms of ppp), demands for Iranian products export would also increase. The positive sign of this variable confirms this claim. After the first stage namely proving sustainable relationship with the critical $\mathrm{F}$, in the second step, collective degree of variables is determined by Schwartz criterion and OLS was estimated by selective model. The result achieved by Microfit statistical software is as follows (Table 3).

Table 3. The results of the estimation model ARDL (2, 1, 2, and 2).

\begin{tabular}{ccccc}
\hline Standard deviation & Coefficient & & Description & Variable \\
\hline 0.11301 & 0.6331 & $1 \beta$ & Export logarithm with a delay & LNX(-1) \\
0.21100 & 0.36148 & $3 \beta$ & Logarithm of importers' income & LNYT \\
0.27860 & -0.65962 & $4 \beta$ & logarithm of Importers' income with a delay & LNYT(-1) \\
0.13575 & 0.15215 & $5 \beta$ & Logarithm of real exchange rate & LNR \\
0.21768 & -0.38887 & $6 \beta$ & Logarithm of real exchange rate with a delay & LNR(-1) \\
0.12639 & 0.13197 & $7 \beta$ & Logarithm of real exchange rate with two delays & LNR(-2) \\
0.40854 & -1.0785 & $8 \beta$ & Logarithm of export price & LNPX \\
0.49917 & 1.3615 & $9 \beta$ & Logarithm of export price with a delay & LNPX(-1) \\
0.48972 & -1.0588 & $10 \beta$ & Logarithm of export prices with two delays & LNPX(-2) \\
$\mathrm{F}=9.5356$ & $\mathrm{R}^{2}=0.944, \mathrm{DW}=2.5029$ & & & \\
\hline
\end{tabular}

Source: research findings.

\section{Conclusion and Recommendations}

Results show that the real exchange rate and importers' income have a positive effect on export demand for livestock and poultry products. On the other hand, increase in added value and export price index of this subsection impact on export demand negatively. Accordingly, it is highly important to consider real exchange rate in order to thrive exportation of livestock and poultry. On this basis, fixed exchange rate policy and control is an important factor in reducing the domestic exports. In this context and despite of executing the subsidies law of subsidies for energy carriers and to increase the competitiveness of domestic exporting goods in the global market, devaluation of national currency can be the most effective policy to increase domestic exports to maintain domestic goods competitiveness. Price index of exporting goods depends on the pricing and international supply and demand. But livestock and poultry products are located in the denominator of domestic prices which have a direct relationship with inflation index. If inflation is controlled in the community, livestock and poultry products price index remains constant. Thus, increase in the price index of export commodities would increase the export of animal products. On the other hand; increase in domestic added value will reduce export demand. This is because that most of the exporting goods under this subsection will be exported with minimal processing. Thus, although increasing the added value will result in reduced exports, the country should look for ultimate target markets rather than markets which import Iranian goods with the of re-export. To increase added value of livestock and poultry products, initiatives should be seriously taken such as technological advancement, productivity increase, using modern tools and methods of knowledge production, etc. Moreover, investment development to transform production methods in livestock subsection from traditional to modern and knowledge-based methods is essential.

\section{REFERENCES}

[1] F. Pasban, "Factors Affecting the Export of Iranian Saffron," Iranian Economic Research Quarterly, Vol. 6, No. 2, 2006, pp. 1-15.

[2] S. Biria and F. J. Ameli, "Factors Affecting the Export of Pistachio, Saffron and Dates in the Basket of Iran Goods Export (1991-2001)," Agricultural Economy and Devel- 
opment Quarterly, Vol. 14, No. 54, 2006, pp. 85-101.

[3] F. Mirzaei, S. M. Mostafavi and S. Yazdani, "Export Comparative Advantage Analysis of Iranian Hen Egg by RCA \& RSCA and RC Criteria," Modern Economy, Vol. 3, No. 5, 2012, pp. 553-556. doi:10.4236/me.2012.35072

[4] K. Khaledi and A. R. Zadeh, "Strengths, Weaknesses, Opportunities and Threats Facing Agricultural Exports," Agricultural Economy and Development Quarterly, Vol. 16, No. 62, 2006, pp. 83-104.

[5] B. Maleki, "New Outlook on Non-Oil Exports: A Case Study of Livestock Products," Institute of Business Studies and Research, Baner Pune, 1996.

[6] S. Khalilian and A. Farhadi, "Factors Affecting Agricultural Exports," Agricultural Economy and Development Quarterly, Vol. 10, No. 31, 2001, pp. 71-84.

[7] A. Shakeri, "Iranian Non-Oil Exports Determinants," Iranian Economic Research Quarterly, Vol. 6, No. 21, 2004, pp. 23-51.

[8] M. Zibaei and M. Mahmoodzadeh, "Factors Affecting Iranian Pistachio Exports: A Cointegration Analysis," Agricultural Economy and Development Quarterly, Vol. 12, No. 46, 2004, pp. 137-157.

[9] K. Noory and M. Kupahy, "Estimates of Demand and Supply Functions Pistachio Exports," Proceedings of the 1st Iranian Conference on Agricultural Economy, Karaj, 5-7 April 1996, pp. 542-553.
[10] H. Tajyany and M. Kupahy, "Estimation of Supply and Demand Functions and Export of Iranian Saffron," Journal of Agricultural Sciences, Vol. 36, No. 3, 2005, pp. 573-580.

[11] S. Fountas and D. Berdin, "Exchange Rate Volatility and Exports: The Case of Ireland," Applied Economics Letters, Vol. 5, No. 5, 1998, pp. 301-304. doi:10.1080/758524405

[12] S. K. Tayebi and A. Ghanbari, "The Impacts of WTO Accession on Iranian Saffron Export Market," 6th Conference of Agricultural Economy, Mashhad University, Mashad, 25-27 October 2007, pp. 868-884.

[13] Gh. Sharzehi and R. Ghanbari, "Estimated Demand and Supply Functions Pistachio Exports," Proceedings of 3rd Iranian Conference on Agricultural Economics, Mashhad, 17-19 February 2001, pp. 666-644.

[14] M. Goldestain and M. Khan, "The Supply and Demand for Export: A Simultaneous Approach," Review Economic and Statistics, Vol. 60, No. 2, 1978, pp. 278-286.

[15] R. Chambers and R. E. Just, "Effects of Exchange Rate Changes on US Agriculture: A Dynamic Analysis," American Journal of Agricultural Economics, Vol. 63, No. 1, 1981, pp. 32-46. doi:10.2307/1239809

[16] H. M. Pesaran and B. Pesaran, "Working with Microfit 4: An Introduction to Econometrics," Oxford University Press, London, 1997. 